\title{
THE STRUCTURAL EVOLUTION OF OCEANIC CORE COMPLEXES: A CONCEPT BASED ON ANALOG MODELING
}

\begin{abstract}
Y. Mart
Recanati Institute of Maritime Studies, University of Haifa, Haifa, Israel

ABSTRACT. Oceanic core complexes are lithological assemblages of predominantly peridotites and serpentinites, located along intersections of some slow-spreading oceanic accreting rifts and fracture zones, embedded in the predominantly basaltic oceanic lithosphere, and fresh and old basalts are juxtaposed across the fracture zone. Centrifugebased experimental models indicated that subduction would initiate at sites where two lithospheric slabs are juxtaposed, provided that the density difference between them is at least $200 \mathrm{~kg} / \mathrm{m}^{3}$ and the friction along their contact plane is low. It was discerned that the modeled underthrust denser lithosphere would reach the modeled asthenosphere and represent tectonic subduction. In many such occurrences, extension in the over-riding slab would develop normal faults that could be penetrated by the lighter fraction of the subducted slab, generating volcanism and diapirism. These experiments suggest further that since the density contrasts and the low friction constraints could be satisfied at the intersections of fracture zones and slow-spreading oceanic ridges, subduction could occur there too and not only along ocean-continent boundaries. Furthermore, since the thermal gradient in ridge-fracture zone intersections is very steep and volatiles in the underthrust slab abound in the subducted slab, a portion of the underthrust basalts would undergo serpentinization and another segment could become peridotitic. It is suggested further that the light serpentinite would ascend through the normal faults in the over-riding slab and reach the seafloor diapirically, carrying along large sections of peridotite, to produce the serpentinite-peridotite petrology that typifies oceanic core complex at junctions of fracture zones and slow spreading ridges.
\end{abstract}

KEYWORDS: density constrained subduction; ridge-transform intersection; oceanic core complexes; peridotites; serpentinites 


\title{
СТРУКТУРНАЯ ЭВОЛЮЦИЯ ОКЕАНИЧЕСКИХ КОРОВЫХ КОМПЛЕКСОВ: КОНЦЕПЦИЯ, ОСНОВАННАЯ НА АНАЛОГОВОМ МОДЕЛИРОВАНИИ
}

\author{
Й. Март
}

Институт морских исследований им. Леона Реканати, Университет Хайфы, Хайфа, Израиль

АННОТАЦИЯ. Комплексы океанических ядер представляют собой литологические ассоциации преимущественно перидотитов и серпентинитов, которые располагаются вдоль пересечений медленноспрединговых океанических рифтов и разломных зон, локализованных в основном в базальтовой океанической литосфере; при этом молодые и древние базальты соседствуют по всей разломной зоне. Модели, разработанные на базе экспериментов с использованием центрифуги, показывают, что субдукция начинается на участках, где две литосферные плиты располагаются рядом друг с другом, при условии, что разность плотностей контактирующих литосферных слэбов составляет не менее 200 кг $/ \mathrm{m}^{3}$, а трение вдоль плоскости их контакта низкое. Установлено, что в предполагаемой модели более плотная литосфера под давлением может достигать астеносферы, что представляет собой модель тектонической субдукции. Во многих случаях растяжение надвигающейся плиты приводит к развитию сбросов, в которые могут проникать более легкие части опускающейся плиты, вследствие чего возникают вулканы и диапиры. Эксперименты показывают, что, поскольку требуемые условия контрастности плотностей и низкого трения могут быть характерны для участков, где разломные зоны пересекаются с медленноспрединговыми океаническими хребтами, процессы, подобные субдукции могут происходить и на таких участках, а не только вдоль границы океан - континент. Более того, поскольку температурный градиент в зоне пересечения океанического хребта и разломной зоны очень высокий и летучие вещества поднадвигового слэба присутствуют в большом количестве в субдуцируемом слэбе, базальты в поднадвиговом слэбе будут частично подвергнуты серпентинизации, а другая часть - перидотитизации. Также можно предполагать, что легкие серпентиниты будут подниматься по сбросам в надвигающийся слэб и достигнут морского дна в виде диапиров, принося с собой большие объемы перидотитов, что приведет к образованию серпентинит-перидотитовых пород, типичных для комплексов океанических ядер на участках, где разломные зоны пересекаются с медленноспрединговыми океаническими хребтами.

КЛЮЧЕВЫЕ СЛОВА: субдукция, обусловленная разной плотностью пород; пересечение хребта и трансформного разлома; комплексы океанических ядер; перидотиты; серпентиниты

\section{INTRODUCTION}

The exploration of the seafloor of the oceans showed that the brittle lithosphere at the mid-ocean ridges and the adjacent terrains comprises predominantly basalts, characterized by their normal and reversed magnetization, which are underlain by gabbro. However already the pioneering scientific cruises encountered, in some select locations, rock sampling and observations of peridotites and serpentinites, which were first attributed to partial melting of xenoliths from the upper mantle, exhumed by the upward flow of the basaltic lavas of the ocean floor (e.g. [Ewing J., Ewing M., 1959]). The abundance of serpentinites was also discerned by Hess [1955], who remarked that serpentinite is highly mobile due to its low density and low cohesive strength, therefore it would tend to flow up diapirically along fault planes.

Subsequently Bonatti [1968], who dredged rubble derived from those peridotites and serpentinites in transform and fracture zone valleys in the Atlantic Ocean, suggested that these valleys offer windows into the deeper layers of the oceanic crust through extensive faulting. Contrariwise, Francheteau et al. [1976] presumed that the transform faults form weakness provinces in the oceanic crust that enable the diapiric ascent of serpentinites, with inclusions of peridotites from the upper mantle. These unique occurrences of peridotites and serpentinites were encountered mostly along slow and ultra-slow oceanic ridges and they were termed "Oceanic Core Complexes" (e.g. [Cann et al., 1997; Tucholke et al., 1998]). They were observed, sampled and drilled, and the co-occurrence of serpentinites and peridotites in some specific sites in the ocean floor, where basalts do not predominate, was verified.

Most outcrops of those serpentinites and peridotites were encountered at the intersection of slow-spreading oceanic ridges and fracture zones, close to the site where the lateral displacement along the transform fault ends and only the structural scar of the fracture zone remains. The abundance of the peridotites in the oceanic core complexes led to the interpretation that these rock suites are derived from the upper mantle. Evidence for strongly shattered series of rocks at the top of many complexes was explained as the product of intensive frictional erosion at their crests during their emplacement along large-throw, low-angle normal detachment faults. Numerous researchers (e.g. [Escartin et al., 2008]) used these observations, as well as analog experiments and numeric models, to develop explanations regarding the activity of the oceanic detachment faults. They founded their arguments on the presumption of low magma supply at the edges of segments of the accretion rift, a shortage that generated large and unique listric faults that were generated not by the downwards collapse of the footwall, known along steep passive margins [Le Pichon, Sibuet, 1981], but by upwards magma injection from the distant upper mantle. 
However, the various interpretations of the generation of the oceanic core complexes based on the large offsets along detachment faults, do not account convincingly for the absence of high-pressure lithologies, such as eclogites, in oceanic core complexes, and Scholz [2002] stated further that seismic evidence for low-angle normal offsets is extremely rare.

Therefore, a novel geodynamic concept is presented to clarify the difficulties in the conventional model of the emplacement of oceanic core complexes. A concept that would account for the occurrence of oceanic core complexes specifically at the junctions of slow-spreading oceanic ridges and the fracture zones that truncate them. A concept that would elucidate the development of the thick layer of fractured mylonites on top of these complexes in places. A concept that would explain the absence of high-pressure minerals in the oceanic core complexes, and would shed light on the co-occurrence of peridotites and serpentinites. Once presented, the validity of such concept could be checked by appropriate numeric modeling.

The present conceptual investigation explored the possibility for a process that would link the exposure of mantle peridotites at the flanks of slow-spreading mid-ocean ridges, their incidental extensive occurrence with serpentinites, and the account for the mylonite on top of some oceanic core complexes. The concept explains how subduction, namely thrust faults that drive denser segments of brittle lithosphere to the proximity of the asthenosphere, is not restricted only to convergent tectonic boundaries between continents and oceans.

\section{METHODOLOGY AND RESULTS}

\subsection{Subduction}

The geodynamic concept that guides the present research is based on two specific series of structural experiments. One generated subduction due to significant contrasting densities of two juxtaposed lithospheric slabs, where the friction between them was low [Mart et al., 2005; Nikolaeva et al., 2010]. The other generated accreting ridge and its transform faults and showed that the faults were formed under geodynamic regime of oblique extension, and that once formed, the larger transform faults would maintain their length throughout their deformation in sandbox or centrifuge experiments [Mart, Dauteuil, 2000; Agostini et al., 2009].

The numerous occurrences of oceanic core complexes at the composite junctions of slow accreting ridges and fracture zones are not random features, but there is reason to presume that such distribution bears tectonic and petrologic significance. Emphasize is dedicated to analog modeling of subduction and transform faulting that are critical to the presented concept.

Subduction is commonly defined as thrust faulting where one plate moves under another and is forced to sink into the mantle. The juxtaposition of two slabs of oceanic crust of contrasting densities across a fracture zone was suggested as a possible cause for the initiation of ocean-ocean subduction, which is an abundant phenomenon [Casey, Dewey, 1984; Dewey, Casey, 2011; Gerya, 2011; Maffione et al.,
2015; Boutelier, Beckett, 2018]. Petrological and geochemical investigations of the lithologies of supra-subduction zones showed the significance of the original mineralogical composition of the subducted slab and the effects of the high pressure and temperature on these parameters on the subducting plate, before its lighter constituents ascended diapirically to the surface as ophiolites or metamorphic core complexes (e.g. [Hawkins, 2003]).

The active initiation of subduction anywhere on earth is very rare, but modelers simulated subduction-like features and commonly suggested that the processes at converging tectonic boundaries between land and sea are constrained by pressure of the oceanic tectonic plate landwards, and by inverse buoyancy of the edge of the oceanic lithosphere. According to such models, the dense and old oceanic slab, which somehow became denser than the underlying asthenosphere, would sink from the surface into the mantle by being pushed into the converging ocean-continent boundary by the remote zone of lithospheric accretion at the mid-ocean ridge. Such working hypothesis was repeatedly used in analog and numeric models (e.g. [Mulugeta, 1988; Chemenda et al., 1995; Stein S., Stein C.A., 1996]). However, inverse lithospheric buoyancy, where the asthenosphere is lighter than the overlying lithosphere, occurs mostly along the oceanic accreting plate margins and in some back-arc basins, but it does not characterize subduction domains. Consequently, unlike the conventional depiction, subduction is not only the underthrusting of oceanic lithosphere under the continents, and density contrasts of juxtaposed tectonic slabs generating ocean - ocean subduction is not rare [Casey, Dewey, 1984], and some $40 \%$ of all subduction zones are intra-oceanic features [Gerya, 2011]. However, the models of all such occurrences require lateral push to initiate and sustain the process [Boutelier, Beckett, 2018].

Centrifuge models at high acceleration showed that two juxtaposed lithospheric plates of contrasting densities, where both were lighter than the asthenosphere, would to initiate underthrusting. The models showed that subduction would initiate where the density contrast between two juxtaposed lithospheric slabs were considerable, and the friction between them were low. Numeric models support these findings [Mart et al., 2005; Goren et al., 2008; Nikolaeva et al., 2010]. The centrifuge experiments showed further that considerable stretching was discernible in the overthrust slab, which would lead to trench roll-back and would drive the forearc domain seawards to an eventually break apart, to form a back-arc basin. Reduced lithostatic load due to breakage of the brittle part of the overthrust slab enabled the ascent and exhumation of buried lithologies in the back-arc domain (Fig. 1).

The deformation in the scaled analog centrifuge experiments that managed to generate subduction without resorting to solutions associated with negative buoyancy or lateral compression but by applying only enhanced gravity could account to findings that subduction is commonly faster than crustal accretion [Jarrard, 1986]. The "asthenosphere" of the experiments was built mostly of painters' putty and the ductile lithospheric slabs - of mixtures 
(a)

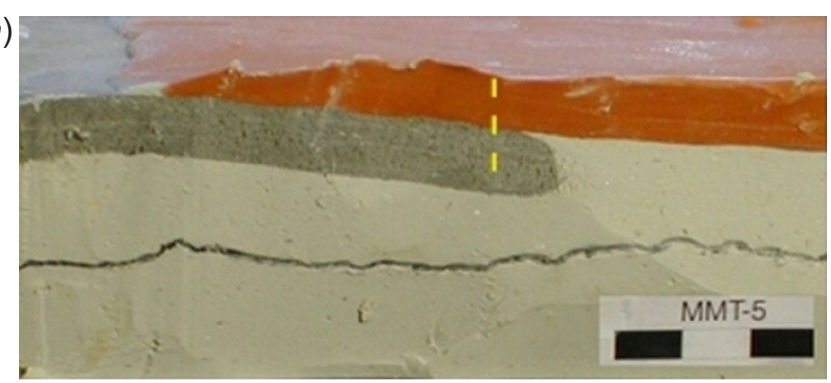

(b)

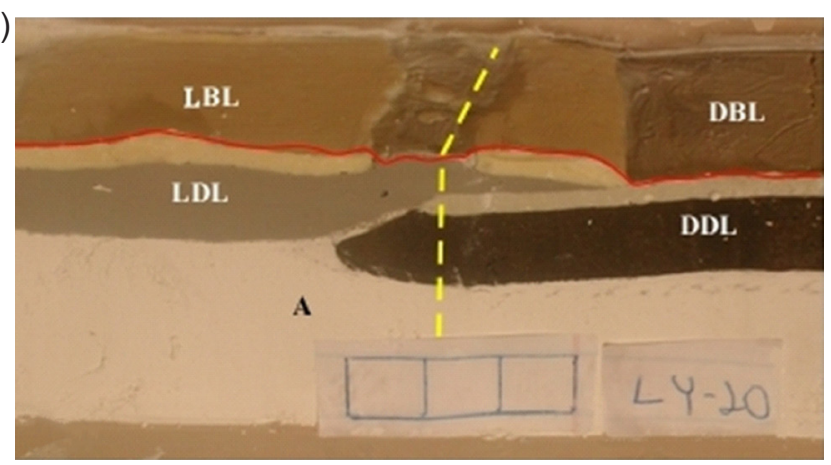

Fig. 1. Calibrated analog experiments show that a denser slab would subduct under a lighter one under deformational constraints of only enhanced gravity in a centrifuge, rotating to produce acceleration of $800 \mathrm{~g}$, without any lateral push.

(a) - section view of a 3-component experiment. a painters' putty and $\mathrm{BaSO}_{4}$ powder was used to model the asthenosphere, and mixtures of silicone, plasticine and $\mathrm{BaSO}_{4}$ powder for lithospheres. Deformation time - 8 minutes. An originally level thin lack layer of graphite, used to measure deformations in the asthenosphere, shows that the distortion within that layer was marginal and deformation took place mostly at the lithosphere. $(b)$ - oblique view of 3-layer, 5-component experiment, representing the asthenosphere (A), topped by denser and lighter lithosphere, with brittle (LBL; DBL) and ductile (LDL; DDL) components, deformed for 75 minutes. While both ductile lithospheres were stretched under the deformation, the lighter brittle lithosphere collapsed and was torn to form a back-arc basin. The discontinuity in the light brittle lithosphere enhanced diapiric ascent and exposure of the light ductile lithosphere. Dashed yellow lines mark the initial juxtaposition of the lighter and denser lithospheres. A fine red line separates the plan view from the section. See Mart et al. [2005] for details.

Рис. 1. Калиброванные аналоговые эксперименты показывают, что более плотный слэб опускается и поддвигается под более легкий слэб при условиях деформации с повышением силы тяжести в центрифуге, вращающейся с ускорением 800 г, без бокового давления.

(a) - модель в разрезе (три компонента). Модельные материалы: астеносфера - шпатлевка (используемая обычно для художественной штукатурки) и порошок сернокислой соли бария $\left(\mathrm{BaSO}_{4}\right)$; литосфера - смесь из силикона, пластилина и порошка $\mathrm{BaSO}_{4}$. Продолжительность деформации - 8 минут. Изначально ровный тонкий слой черного графита, используемый для измерения деформаций в астеносфере, показывает, что нарушения в этом слое были незначительными и деформации происходили в основном в литосфере. (b) - модель, состоящая из трех слоев, включающих пять компонентов. А - астеносфера; сверху более плотная литосфера; хрупкие (LBL и DBL) и пластичные (LDL и DDL) компоненты под действием деформации в течение 75 минут. За то время, пока оба пластичных компонента литосферы растягивались под действием деформацией, произошло разрушение и разрыв более хрупкой литосферы, при этом сформировался задуговый бассейн. Из-за разрыва хрупкой литосферы усилился подъем диапиров и воздействие на пластичную литосферу. Желтая пунктирная линия - первоначальное положение более плотных компонентов литосферы. Тонкая красная линия отделяет вид сверху от разреза. Детальное описание модели приведено в [Mart et al., 2005].

of plasticine and HDMS silicone. Densities were adjusted with $\mathrm{BaSO}_{4}$ powder, and the deformation was generated by accelerating the centrifuge to $800 \mathrm{~g}$. Density difference between the juxtaposed slabs was ca. $200 \mathrm{~kg} / \mathrm{m}^{3}$ and the friction between them was reduced by lubrication [Mart et al., 2005]. The modelers presumed that the increasing pressure and temperature at the underthrust slab at the natural depth of mid-lithosphere, (approximately $40 \mathrm{~km}$ ) would enhance the remineralization of pyroxenes into garnets and similar eclogitization processes under dry conditions. Such metamorphic processes would gradually increase the density of the down-going slab and enable its sinking into the asthenosphere. Additional presumption was that the availability of water in the heated subducted plate would enhance mineral hydration, which would produce lightdensity derivatives of the basalts like serpentinites. Serpentine could ascend diapirically and exhume (Table). Lateral push would have probably enhanced the underthrusting process (e.g. [Shemenda, 1993; Mulugeta, 1988; Chemenda et al., 1995; Scholz, Campos, 1995]), but the centrifuge calibrated analog experiments generated subduction without it.

Examples of wet and dry remineralization processes and the densities of their products at approximate depth of $\sim 40 \mathrm{~km}$ and temperature of $\sim 500{ }^{\circ} \mathrm{C}$. After Turner and Verhoogen [1960]. Numbers display densities in $\mathrm{kg} / \mathrm{m}^{3}$

Примеры процессов влажной и сухой реминерализации и плотности пород (кг/м³) на глубинах около 40 км при температуре около $500{ }^{\circ} \mathrm{C}$ (по [Turner, Verhoogen, 1960])

\begin{tabular}{|c|c|c|c|c|c|c|c|}
\hline & & & Wet & & & & \\
\hline \multirow{3}{*}{$\begin{array}{c}\text { olivine + } \\
3210 \\
\end{array}$} & water + & silica & $\longrightarrow$ & serpentine & & & [1] \\
\hline & & & & 2510 & & & \\
\hline & & & Dry & & & & \\
\hline $\begin{array}{c}\text { labradorite + } \\
2700\end{array}$ & $\begin{array}{c}\text { olivine + } \\
3210\end{array}$ & $\begin{array}{c}\text { diopside } \\
3280\end{array}$ & $\longrightarrow$ & $\begin{array}{l}\text { garnet + } \\
\sim 3700\end{array}$ & $\begin{array}{c}\text { omphacite + } \\
3300\end{array}$ & $\begin{array}{l}\text { quartz } \\
2650\end{array}$ & [2] \\
\hline
\end{tabular}




\subsection{Some characteristics of transform faults and fracture zones}

Since most oceanic core complexes are located at the intersections of accreting oceanic ridges and the edge of the translation domain, where transform faults are converted into fracture zones, some deliberation regarding transform faults seems useful. The concept of transform faults as a new, non-Andersonian type of faults was suggested by Wilson [1965] and served as one of the cornerstones of plate tectonics. Such faults have a relatively short active segment, where lateral displacement takes place between two active segments of accreting ridges, and they leave behind very long scars in the seafloor, the fracture zones, that are tectonically inactive, and commonly extend across the entire ocean basin. Oceanic core complexes are thus bounded by two orthogonal structural valleys - the mid-ocean rift and the fracture zone gorge.

Analog modeling showed that ridge offsets along trans form faults take place under oblique extension at the early stages of the evolution of the accretion ridge (e.g. [Mortimer et al., 2007; Taylor at al., 2009; Gerya, 2011; Brune at al., 2018]), whereas ridges affected by normal extension are likely to produce unfaulted structures, like Reykjanes Ridge, that extends from Iceland southwards for nearly $1000 \mathrm{~km}$ without being offset by a transform fault. Small offsets, formed under oblique externsion, are likely to merge into the expanding mid-ocean rift, but larger ones will develop into mature transform faults, (e.g. [Mart, Dauteuil, 2000; Agostini et al., 2009]), transforming

(a)

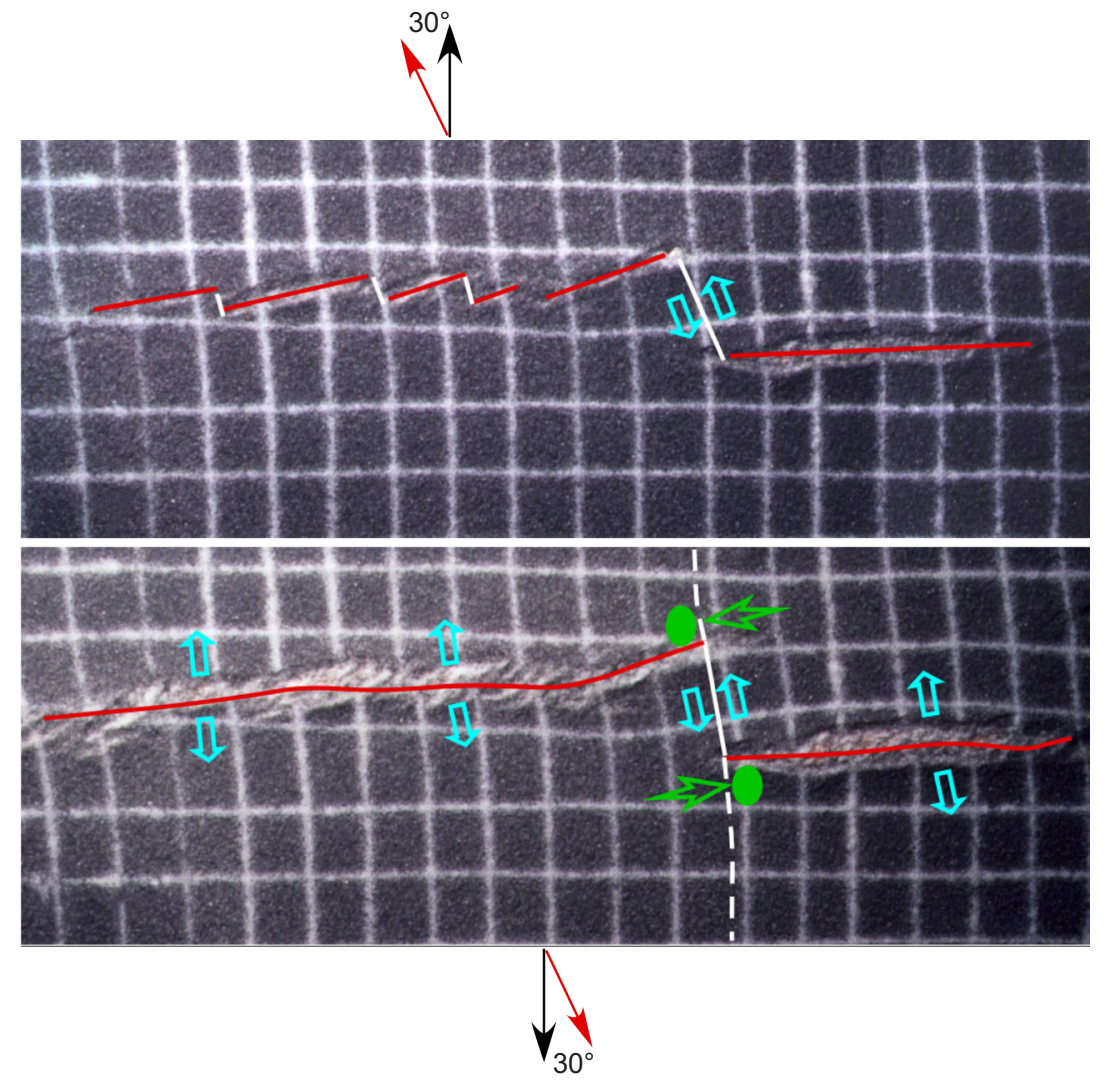

Fig. 2. Sandbox analog model shows jumps of the axial mid-ocean rift and the subsequent evolution of the transform faults.

$(a)$ - the initial stage of the accreting ridge and $(b)$ - its advanced structural extension. Note that the length of the larger transform fault did not increase with deformation but remained stable, whereas the small transform faults were merged into the expanding rift. The rift jump was caused by the $30^{\circ}$ obliquity of the extension. Blue arrows show the plates' motion, red lines show the track of the midocean rift, green arrows show the position of the possible mid-ocean ridge subduction and the green circles show the expected site of the oceanic core complexes, solids white line shows the transform fault and dashed white lines show the expected track of the fracture zones. After Mart and Dauteuil [2000].

Рис. 2. Скачки осевого разлома в срединно-океаническом хребте и последующее развитие трансформных разломов, установленные в экспериментах с аналоговой моделью из песка.

$(a)$ - начальная положение хребта; $(b)$ - положение хребта после растяжения. Длина крупного трансформного разлома не увеличивалась в ходе деформации, а оставалась стабильной. При этом небольшие трансформные разломы объединились, сформировав растущий рифт. Причина скачка рифтообразования - косое растяжение под углом $30^{\circ}$. Голубые стрелки направление движения плит; красная линия - трасса срединно-океанического хребта; зеленые стрелки - возможная субдукция срединно-океанического хребта; зеленые точки - ожидаемое положение комплексов океанических ядер; сплошная белая линия - трансформный разлом; пунктирные белые линии показывают ожидаемую трассу зон разрушения. По [Mart, Dauteuil, 2000]. 
the crustal accretion from one active segment of the rift to the next (Fig. 2).

Once formed, transform faults host lateral offsets due to crustal accretion along the ridges at their edges. These offsets leave a significant scar in the oceanic crust that is discernible at the seafloor along the fracture zones away from the ridges, where lateral displacement does not occur, and the two slabs across the fracture zone move together away from the ridge. Some vertical offsets along the fracture zones due to density differences of the crustal slabs juxtaposed along them keeps the contact plane along the fracture zone fragile [Sclater, Francheteau, 1970]. The continuous offset along the transform faults does not change their length with time, but once formed, their length is stable [Mart, Dauteuil, 2000].

Fracture zones are distinguished by their deep valleys, their physiography varied due to variable offset patterns along them when they were still active transform faults [Dick, 1989]. They commonly display gorges up to $6 \mathrm{~km}$ deep and their width in most sites is circa $20 \mathrm{~km}$, but in extremity, it reaches $40 \mathrm{~km}$, such as in Garrett Fracture Zone [Hekinian et al., 1995]. Not only were basalt and peridotite dredged in fracture zone valleys, but also gabbro, amphibolite, greenschist and serpentinite were sampled along these valleys and their walls [Dick, 1989].

Accreting mid-ocean rifts are distinguished by the shallow depth of the top of the mantle under their axes, where asthenospheric temperatures of $\sim 1300^{\circ} \mathrm{C}$ were expected to occur at depth of circa $10 \mathrm{~km}$. Due to the estimated $130^{\circ} / \mathrm{km}$ thermal gradient at the domain of the accreting tectonic boundary, it is plausible to presume that at the junction of the fresh mid-ocean ridge basalt with older oceanic brittle lithosphere across the fracture zone, the contrast of densities between these juxtaposed lithospheres would be considerable. The slower the spreading rate, the larger the density contrast would be for the same transform fault offset. Where that contrast exceeds $200 \mathrm{~kg} / \mathrm{m}^{3}$, experiments suggest that it seems plausible that the denser lithosphere would sink along the fracture zone, initiate subduction, and then it would undergo metamorphic remineralization of high temperature - low pressure at relatively shallow depths.

The availability of water in such subducting constraints would lower the melting temperature of pyroxenes and olivines considerably. Where the descent of the older slab is interrupted, and cooling takes place, co-occurrence of peridotite and serpentinite seems plausible (Fig. 3). Indeed pyroxene, under normal subduction environments, with the presence of less than $5 \%$ water, would remineralize into garnet at depth of ca. $60 \mathrm{~km}$ and temperatures of $400-550{ }^{\circ} \mathrm{C}$, which is a significant part of the eclogitization process [Ahrens, Schubert, 1975]. However, the rareness of garnets in oceanic core complexes suggests that the peridotites and the serpentinites in these domains formed at high temperatures but at shallower depth, compatible with the extreme thermal gradients of the accretion ridge.

\subsection{Geodynamic setting of oceanic core complexes}

While the perception of subduction of the oceanic crust under the continent was minted by Benioff [1951], the concept of ocean-ocean subduction was elaborated by Casey and Dewey [1984], and it was modeled analogically and numerically as well (see [Gerya, 2011, Boutelier, Beckett, 2018] and references therein). They emphasized the physical variabilities of the terrains where subduction could take

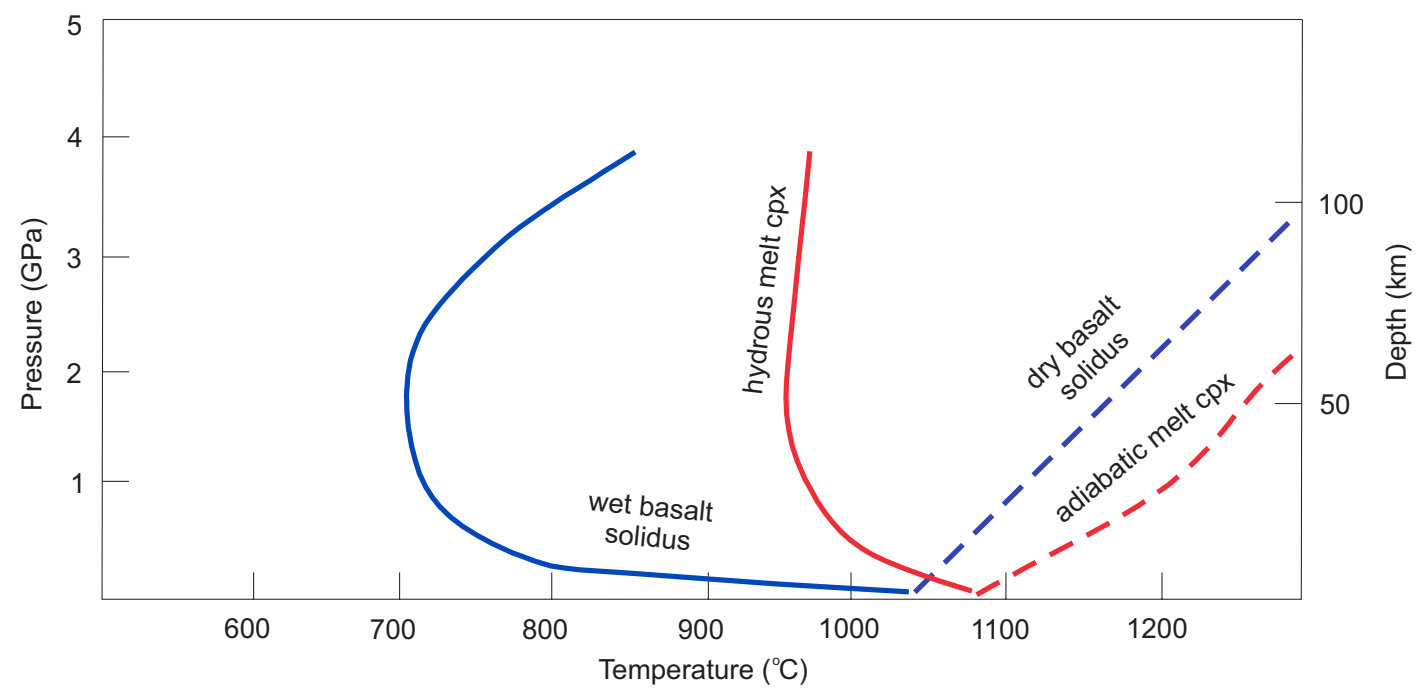

Fig. 3. Presence of water in the subducting slab would lower the melting temperature of the oceanic lithosphere to $700{ }^{\circ} \mathrm{C}$. At normal subduction zones, such temperature occurs at lithostatic pressures of ca. $2 \mathrm{GPa}$, or depth of $\sim 50 \mathrm{~km}$, but at oceanic core complexes such temperatures would occur at depth of ca. 5-7 km. Note the sharp drop of the solidus of wet basalt at temperatures circa $700{ }^{\circ} \mathrm{C}$. cpx - clinopyroxene. Red lines are after Katz et al. [2003] and blue lines are after Kessel et al. [2005].

Рис. 3. При наличии воды в плите, подвергающейся субдукции, температура плавления океанической литосферы может понизиться до 700 ㄷ. В зонах нормальной субдукции температура достигает такого уровня при литостатических давлениях примерно 2 ГПа или на глубинах примерно 50 км. В комплексах океанических ядер такая температура может быть на глубинах около 5-7 км. Следует отметить резкое падение солидуса влажного базальта при температурах около $700{ }^{\circ} \mathrm{C}$. Срх - клинопироксен. Графики: красный - по [Katz et al., 2003]; голубой - по [Kessel et al., 2005]. 
place, and suggested that juxtaposition of tectonic slabs of different age and density across a fracture zone would enable ocean-ocean subduction. That presumption, and the observations from analog experiments that subduction could start without lateral push [Mart et al., 2005], raised the plausibility that subduction could also account for the unique petrology of oceanic core complexes, by taking place along crustal weakness zones, provided that the structural requirements for sufficient density contrast and low-friction contact zone would be satisfied there.

Commonly, the two facing flanks of the accretion rift, belonging to two discrete tectonic plates, are symmetric, built of fresh basalts and deformed by normal faults. However, in oceanic core complexes, only one flank of the accretion ridge is basaltic, while the other, bounded by both the accretion rift and the fracture zone, is built by variety of rocktypes, where peridotites and serpentinites are abundant (e.g. [Kelemen et al., 2007]). The sites of oceanic core complexes are distinguished by being edge features, they develop at the edge of the accreting rift, but also at the edge of the transform fault, where it becomes seismically and dynamically inactive. Plausibly, the oceanic core complexes are not the original setting of the edges of the ridge segments (Fig. 4), but the complexes penetrated into the original basaltic lithosphere and displaced it.

The conventional explanation to the emplacement of oceanic core complexes is that the lower part of the oceanic lithosphere is exhumed there due to very large offset along

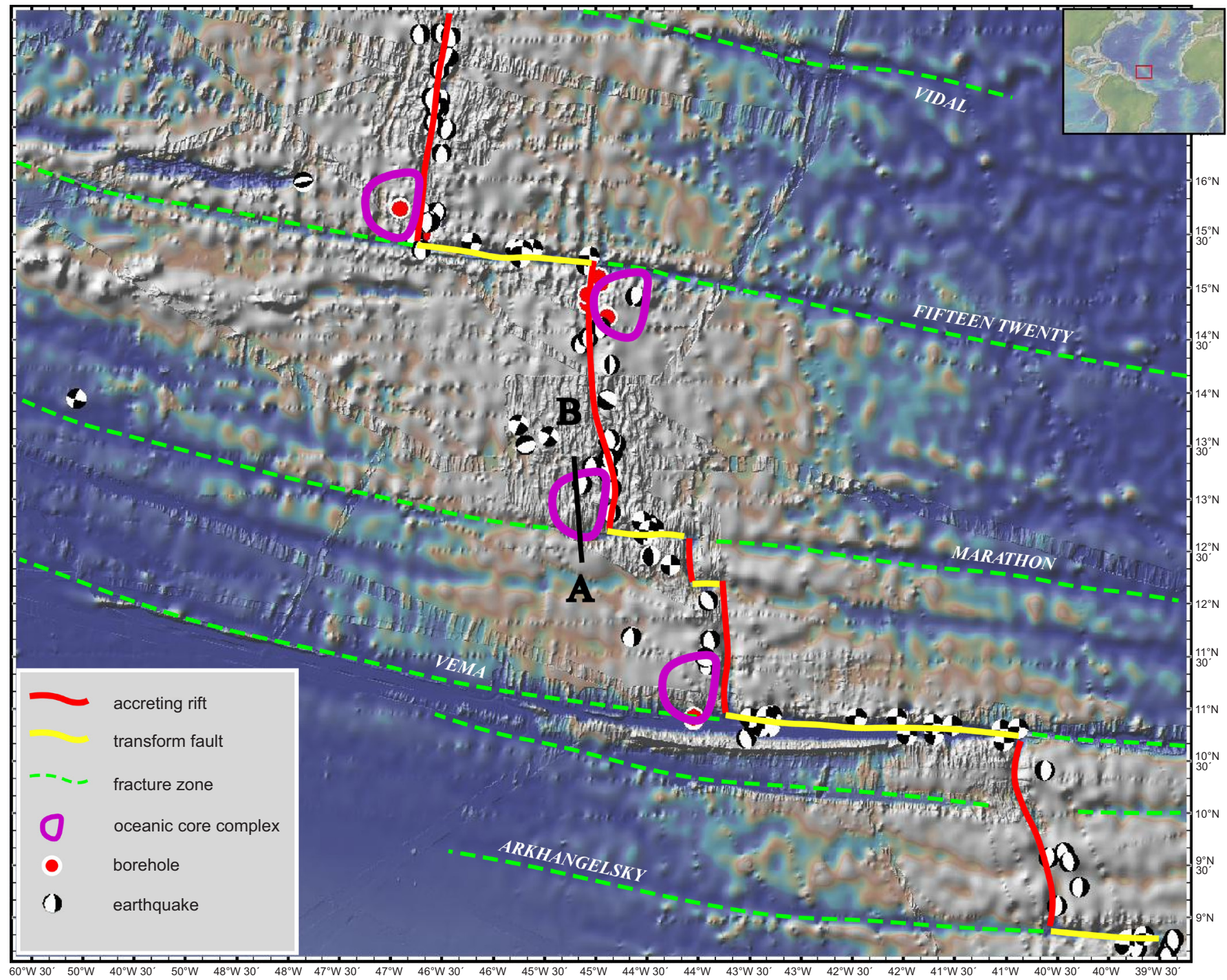

Fig. 4. The location of several of the oceanic core complexes, in the Equatorial Atlantic Ocean, shows that they occur at junctions of where accreting ridges are truncated and offset, and transform faults turn into fracture zones. Most oceanic core complexes share such setting. Note that earthquake solutions show extension along the rift and strike-slip offsets along the transform faults, but almost no earthquakes were recorded along the fracture zones.

Рис. 4. Места расположения ряда комплексов океанических ядер в экваториальных районах Атлантического океана свидетельствуют о том, что они образуются в зонах сочленения, где хребты срезаются и смещаются, а трансформные разломы переходят в зоны трещиноватости. Большинство океанических комплексов ядер сформировались в такой обстановке. Следует отметить, что механизмы очагов землетрясений показывают растяжение вдоль рифтов и сдвиговые смещения вдоль трансформных разломов, однако практически не зарегистрировано землетрясений вдоль зон трещиноватости. 
(a)

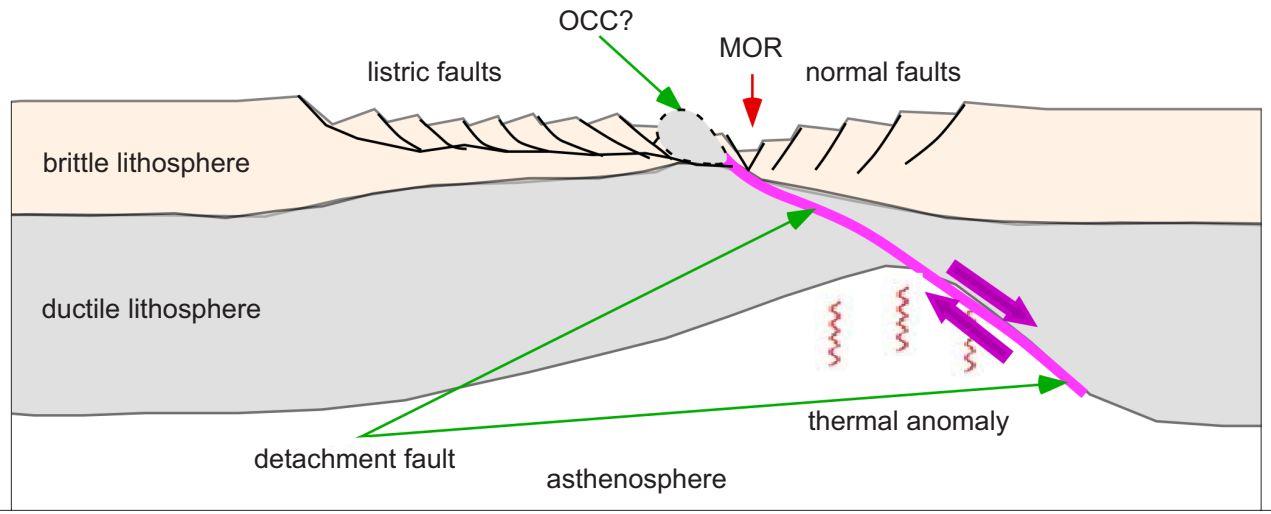

(b)

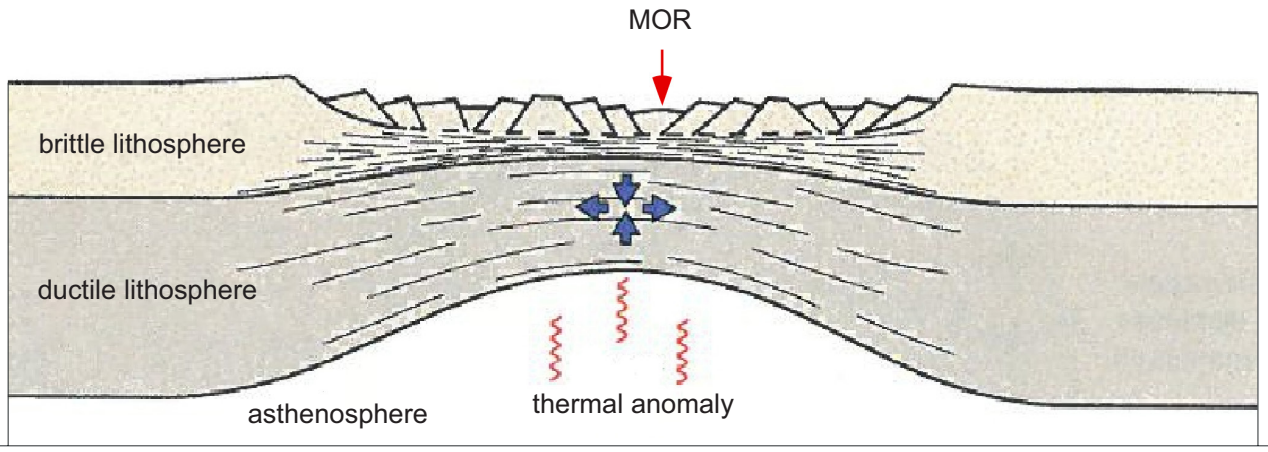

Fig. 5. (a) - schematic presentation of the concept suggesting that oceanic core complexes are exhumed from the upper asthenosphere through low-angle, intensive offset of normal offset of a marine detachment fault.

The serpentinization of the mantle peridotites took place during the ascent voyage. After Wernicke [1985]. (b) - McKenzie's [1978] concept of crustal accretion due to asthenospheric ascent under the Mid-Ocean Ridge is the accepted model of crustal accretion. The protrusion from the ductile lithosphere marked OCC? and surrounded by a dashed line, should have originated in the lower lithosphere upper asthenosphere After Fossen [2016]. The thick purple line represents the alleged detachment fault, MOR - Mid Ocean Rift, OCC - oceanic core complex.

Рис. 5. (a) - схематическое представление концепции, предполагающей, что океанические комплексы ядер эксгумируются из верхней астеносферы при интенсивном смещении по пологому нормальному сбросу вдоль морской зоны детачмента. Серпентинизация мантийных перидотитов происходила во время их подъема. По [Wernicke, 1985]. (b) - общепринятая модель аккреции земной коры по [McKenzie, 1978] вследствие подъема материала астеносферы под срединно-океаническим хребтом. Выступ пластичной литосферы (обозначение OCC?, контур пунктирной линией) возник в нижней литосфере - верхней астеносфере. По [Fossen, 2016]. Фиолетовая линия - предполагаемый разлом; MOR - срединно-океанический рифт; ОСС комплекс океанического ядра.

normal detachment faults, where the roots of those fault planes reach at the top of the asthenosphere, reviving Wernicke's [1985] concept of simple shear along the accretion ridges. Fig. 5 presents some of the differences between the simple shear (a) and the pure shear concept [McKenzie, 1978]. According to the concept that oceanic core complexes are formed by detachment faults, mantle peridotites were serpentinized during their long journey from the base of the brittle lithosphere to the surface along a fault dipping less than $25^{\circ}$. Friction during that journey would produce a thick series of rubble and breccia at top of the lithologic complex, which were commonly discerned (e.g. [McCaig et al., 2010]). However, already Scholz [2002] claimed that there is no seismic evidence that low-angle normal faults do exist.

Presumably, the structural block that is located adjacent to the oceanic core complex, across the fracture zone valley, could be associated with the evolution of the core complex as well. The slab across that valley is built of older basaltic oceanic lithosphere, with density of ca. $2900 \mathrm{~kg} / \mathrm{m}^{3}$, while the estimated density of the fresh basaltic lithosphere in the accretion ridge is $2700 \mathrm{~kg} / \mathrm{m}^{3}$. Density contrast of $200 \mathrm{~kg} / \mathrm{m}^{3}$ was found sufficient to generate subduction in the centrifuge analog experiments [Mart et al., 2005; Goren et al., 2008]. Additionally, the border between these older and fresh lithospheres is a weakened plane due to the offsets of the transform fault displacement, which could enable and enhance the subduction of the denser slab.

As the underthrust slab is driven into the subsurface along the fracture zone near the edge of the accreting rift, the rising temperature of the adjacent asthenosphere and the availability of seawater along the fracture zone itself would enhance the remineralization of some of the pyroxene into serpentinite, while some dry sections would become peridotitic (Table). There is likelihood that the serpentinite would form diapirs that will ascend to the seafloor, carrying along blocks of peridotites, similar to such features encountered in ophiolitic occurrences, such as the Troodos 


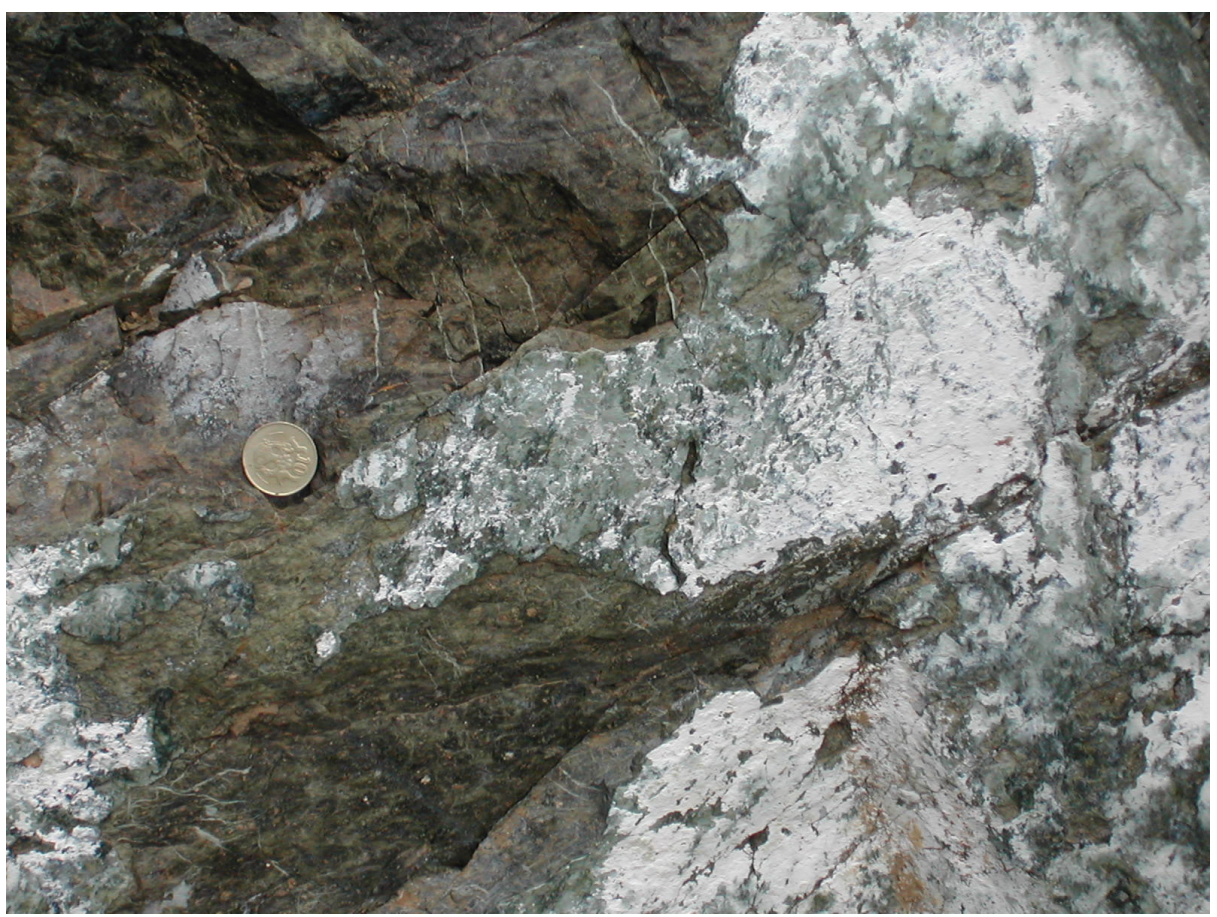

Fig. 6. Peridotite (dark gray) embedded in serpentinite and asbestos (light shades) in a quarry in the Troodos Massif in Cyprus. Note the intimate spatial relations between the serpentinites and the peridotites, and the fine serpentinite veins within the peridotite.

Рис. 6. Перидотит (темно-серый цвет) в серпентините и асбесте (светлые тона) в карьере в горном массиве Троодос (Кипр). Следует отметить близость серпентинитов и перидотитов в пространстве и тонкие жилы серпентинита внутри перидотита.

Mountains in Cyprus (Fig. 6). However, if the densities contrast between the juxtaposed slabs would be too low or the friction between the slabs too high, then the evolution of the oceanic core complex would not take place.

At the junction where the accretion ridge and the fracture zone converge, lithospheres of near-normal and uniquely low-density basalts are juxtaposed across a vertical weakness zone. If the length of the transform offset is some $200 \mathrm{~km}$ and the accretion rate of the Mid-Ocean ridge is $3 \mathrm{~cm} / \mathrm{yr}$, the age difference across that junction is nearly $7 \mathrm{Ma}$. Then the density contrast across the fracture zone would probably exceed $200 \mathrm{~kg} / \mathrm{m}^{3}$, and the centrifuge experiments suggest that the denser plate will sink under the lighter one (Fig. 1, 7), whereas at faster spreading rates, the older plate would be too light and the density contrast would be insufficient to generate the initiation of subduction. Once subduction were generated, remineralization of the crustal basalt and gabbro into serpentinite and peridotite would take place, generating diapiric ascent of the light and ductile hydrosilicates. As the diapirs force their way upwards, rubble and berccias are likely to accumulate at their crests due to friction. Furthermore, while the subducted segments of the older lithosphere would be driven away from the ridge-transform fault - fracture transition zone due to continued crustal accretion at the ridge, the densities contrasts are likely to diminish and the subduction processes would terminate. That is the reason why oceanic core complexes are restricted to accretion ridge fracture zone intersections.
The marine geological and geophysical research of oceanic core complexes found out that although many such features were encountered in the Equatorial Atlantic Ocean (Fig. 4), such core complex lithologies were dredged, observed and drilled also in the SW Indian Ocean (e.g. [Dick, Bullen, 1984; Dick, 1989]), and in Parece Vela back-arc basin in the western Pacific [Ohara et al., 2001]. Oceanic core complexes were also discerned in the very fast-spreading East Pacific Rise at its intersection with Garrett transform Fault at 13²8'S (e.g. [Cannat et al., 1990; Hekinian et al., 1995; Constantin et al., 1995]).

The presented concept of the generation of oceanic core complexes presumes two stages of their evolution. The first is the underthrusting of relatively cold lithospheric slab from across the fracture zone junction under the external flank of the slow-spreading Mid-Oceanic Ridge (Fig. 4), where sufficient density contrast between the two slabs occurs. Considering the exceptional thermal gradient in the ridge province, the high temperature and low pressure, the underthrust slab would undergo remineralization in two paths. The water-rich parts of the downgoing slab would undergo serpentinization, but the remineralization of the drier parts would become peridotitic (Table). The second stage in the core complex development is diapiric ascent of the lighter rock suites of the sinking slab upwards into the ridge flank, bounded by the orthogonal tectonic weakness zones, the accreting rift and the fracture zone. The ascent of these diapirs would generate a crushed zone of rocks at the top of the diapirs, where most 


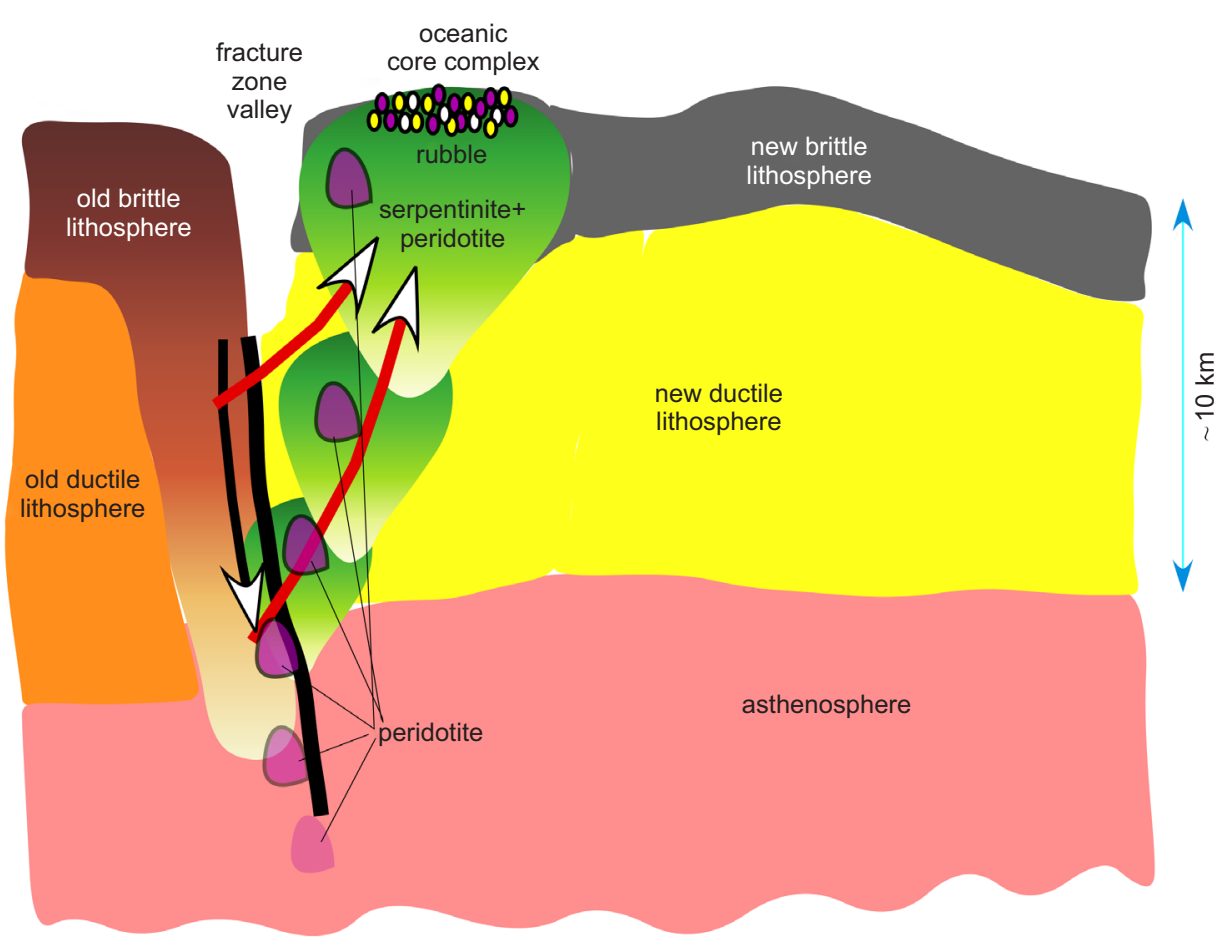

Fig. 7. Schematic geological cross-section, where the juxtaposition of very fresh against older lithospheres triggered the subduction of the denser slab along the fracture zone due to differential densities and low friction.

Metamorphic processes would change the basalts into either serpentinite or peridotite, depending on the availability of water. The serpentinites are likely to ascend diapirically into the overlying slab, accreting rubble at its top due to friction at the top of the diapir. The ascent would probably take place along a weakness zone in the over-riding tectonic plate generated by structural extension block, carrying along blocks of peridotite. Most of the peridotite would sink into the asthenosphere and merge into that mass as the subducted blocks get heated.

Рис. 7. Схематический геологический разрез. Наложение новейших и более древних литосферных материалов - триггерный механизм субдукции более плотного слэба по разломной зоне из-за разности плотностей и низкого трения.

Процессы метаморфизма могут привести к замене базальтов серпентинитами или перидотитами, в зависимости от наличия воды. Серпентиниты склонны подниматься в виде диапиров в вышележащий слэб, при этом происходит аккреция обломков пород на его верхней поверхности из-за трения в верхней части диапира. Вероятно, подъем материалов происходит по ослабленной зоне надвигающейся тектонической плиты, которая формируется вследствие структурного растяжения, смещающего блоки перидотита. Большая часть перидотита погружается в астеносферу и сливается с материалом астеносферы при нагревании субдуцированных блоков.

of the upwards friction associated with the diapirization would focus (Fig. 7). The rareness of oceanic core complexes along the proximal flanks of the accretion ridge, the one that borders the transform fault, could indicate that the lateral offsets there interfere with the initiation of the subduction.

It is plausible that the structural setting at the fracture zone and the slow oceanic ridge intersection would be favorable for subduction because it offers a unique environment of very high temperatures, low lithostatic pressures, and abundant seawater to enhance serpentinization. The upwards motion of the hydrous silicates, generated under such constraints, would likely carry upwards large peridotite xenoliths that occur on its upwards path (Fig. 7).

\section{DISCUSSION}

The two basic geologic characteristics of oceanic core complexes are their common occurrence along the external flank of slow-spreading Mid-Ocean Ridges at its intersection with fracture zones, and their petrology of abundant co-occurrence of metamorphic serpentinites and magmatic peridotites. While the data describing these complexes are abundant, their prevailing geodynamic interpretation seems ambiguous. Many investigations interpreted the tectonic regime of the oceanic core complexes as the products of extensional detachment faults. These low-angle normal faults allegedly transect the entire lithosphere and displace their footwalls by tens of kilometers (Fig. 5), they are non-Andersonian and cannot be restored (e.g. [McCaig et al., 2010]).

Dick [1989] noticed that many of the rocks dredged in transform valleys and fracture zones are peridotites and serpentinites. He compared this finding with the relatively low content of basalt and gabbro in his samples, and attributed these observations to a model where a thin veneer of pillow basalt that erupted directly on serpentinized mantle peridotite, and in places where the magma supply was low, the mantle was exhumed directly on the seafloor. Furthermore, due to the scarceness of basalt and gabbro, he suggested that either the magma flowed laterally in the mantle beneath the fracture zone, or instead, the peridotites were part of an upwelling mantle diapir that flowed 
to the fracture zone after melt segregation. That feeding mechanism differed from the magma supply to the divergent ridge that reached seafloor directly from the magma chamber, hence the variable petrology.

Indeed the source of oceanic core complexes is commonly attributed to peridotitic and serpentinitic lithologies from the distal deep crust - upper mantle domains, which are driven into slow ridge - fracture zone intersections, due to normal detachment faults (e.g. [Parnell-Turner et al., 2017]). These faults supposedly uplift the peridotitic and serpentinitic lithologies of the footwall from the distal upper mantle to the seafloor on one flank of the median rift, while the conjugate flank remains built of regular oceanic crust of basalt and gabbro, and forms the hanging-wall of the detachment fault (cf. [Whitney et al., 2013] and references therein). However, since the computed restoration of the offsets of detachment faults is commonly very difficult, because the presumed offsets substantially exceeds the thickness of the oceanic crust [John, Cheadle, 2010], the validity of the detachment fault model is equivocal (q.v. [Scholz, 2002]).

Several investigations showed petrologic correlation between peridotites and serpentinites of oceanic core complexes and the mantle underneath the Mid-Ocean Ridge. Mevel [2003] presented evidence that the protolith, from which the serpentinite of oceanic core complexes were generated, was oceanic crust gabbro. She suggested that the occurrence of the serpentinites indicates seawater content of nearly $15 \%$ in the source rock, and that temperatures of circa $500{ }^{\circ} \mathrm{C}$ were required for the serpentinization reaction of gabbro to take place. Mevel [2003] argued that such temperatures probably prevail at magma chambers, at shallow depth under the mid-ocean ridge. This evidence for a proximal source for the major constituents of the oceanic core complexes is in agreement with present tectonic concept.

The investigations of the cores of boreholes drilled during ODP leg 157 at the complexes at the Mid-Atlantic Ridge, led Andreani et al. [2007] to presume that oceanic core complexes were formed due to the ascent of lithological matter from the upper mantle. The occurrence of the complexes at the intersection of slow divergent tectonic centers and transform faults was derived from very large offset by detachment faults. They ruled out the possibility that the proximity of the upper mantle under the accreting ridge could be the source of the serpentines of the oceanic core complex.

A series of well-documented oceanic core complexes are those of the north-central Atlantic Ocean, such as the Kane oceanic complex on the Mid-Atlantic Rift, where the oceanic core complex forms an elevated terrain on one flank of the rift, which faces the basalt-gabbro oceanic crust on the other. In that province of slow spreading accreting ridge, the explorers argued for a large detachment fault that was active from 3.3 to $2.1 \mathrm{Ma}$, exhuming variable deep crustal and upper mantle lithologies that include peridotites, basalts, gabbros as well as diabases, greenschists and serpentinites [Knott et al., 1998; Kelemen et al., 2007]. ODP legs 158 and 209 , which drilled in these domains respectively, encountered similar lithologies. Dick et al. [2008] interpreted the exhumation of that oceanic core complex as the product of local instabilities in the mantle feeding into the accretion ridges, where the fixed weakness zones focused episodes of melt intrusions. However, alternately, the Kane core complex could have stopped its activity because the Mid-Atlantic accretion rate became somewhat faster, and the older juxtaposed slab became warmer and lighter and the subduction stopped.

Comparative multidisciplinary studies at the Mid-Atlantic Ridge of the Atlantis Massif at $30^{\circ} \mathrm{N}$ and the Fifteen Twenty massif at that latitude emphasized the occurrence of thick series breccia that altered into talc-tremolite-chlorite schist on top of both those oceanic core complex. The evidence of temperatures of 600 to $700{ }^{\circ} \mathrm{C}$, which prevailed during the hydrothermal alteration, distinguishes these two massifs. It was suggested that the low temperature was probably caused by hydrothermal circulation along the permeable detachment fault plane [McCaig et al., 2010]. However, here again it should be noted though that the peridotite-serpentinite footwall could have been emplaced not only by detachment faulting, but by diapiric ascent, and the friction at the top of the ascending diapirs could have generated the observed crushed and altered lithologies.

At the intersection of the Mid-Atlantic Rift and the fracture zone at $22^{\circ} 19^{\prime} \mathrm{N}$, Dannowski et al. [2010] carried out multidisciplinary investigations, applying oblique seismic reflection and seismic refraction surveys, as well as gravity measurements and seafloor sampling. They confirmed previous observations that where oceanic core complexes outcrop, the mid-ocean ridge is not symmetric. They noticed that while the flank built of normal oceanic crust merges gradually with the adjacent lithology, the transition of the core complex into the adjacent lithology is abrupt. Dannowski et al. [2010] remarked that the depth to the Moho under the core complex is some $40 \%$ thinner than its depth under the nearly contemporaneous normal crust on the conjugate margin of the mid-ocean rift. They attributed the contrast in Moho depth across the mid-ocean ridge in core complex provinces to displacement of tens of kilometers along those large detachment faults and its massive supply of upper mantle material (Fig. 5).

The co-occurrence of peridotite, the representative lithology of the upper mantle, and serpentinite, its hydrated derivative, is probably the results of the presence of water at depths along the weakness plane of the fracture zone, where the prevailing temperature is circa $500^{\circ}$. The hot seawater lowered the solidus of both basalt and peridotite and enabled the serpentinization (q.v. [Kessel et al., 2005]). Consequently, differences in the interpretations of the lithological observations and their tectonic significance regarding the various oceanic core complexes and other cooccurrences of peridotites and serpentinites [Sibuet, $\mathrm{Tu}$ cholke, 2013], led Whitney et al. [2013] to suggest that the size, the structural style, and the lithology of the oceanic core complexes was determined by their rheological constraints. They suggested that distinct oceanic core complexes would develop from variation in the composite system of pressure, temperature, fluid content and time of mantle exhumation. 
Evidence for structural intrusion of peridotite and serpentinite from the asthenosphere through the lithosphere into the intersection of the Mid-Atlantic Ridge and the fracture zone at $16^{\circ} \mathrm{N}$, and the subsequent tectonic uplift of that site, was reported by Cannat et al. [1992]. They suggested that the extensional tectonic regime along the axial zone of the Ridge led to the emplacement of the peridotite-serpentinite body and its exhumation on the seafloor. Subsequent investigation of Cannat et al. [1995] of the core complexes at latitudes $22-24^{\circ} \mathrm{N}$ of the Mid-Atlantic ridge, showed correlation between positive free-air gravity anomalies and occurrence of ultramafic lithologies, which led them to presume that tectonic uplift introduced the ultramafic rocks into the transform valley. Ghose et al. [1996] remarked that such uplift was not uniform along the transform valley, because evidence for partial melting was less pronounced along the Kane transform fault than along transform faults of lesser offset in that domain of the slowspreading Atlantic ocean.

The asymmetric lithology of the Mid-Atlantic Ridge was estimated to encompass very large tracts in the central MidAtlantic Ridge where normal basaltic-gabbroidic brittle lithosphere on one flank of the ridge would face wall of serpentinite and other metamorphic lithosphere at the conjugate flank. Smith et al. [2006] and Escartin et al. [2008], who described that distribution, attributed it to the tectonic significance of active and extinct detachment faults in the evolution of oceanic core complexes.

The hydrous geochemistry of mafic and ultramafic magmas plays a critical role in the petrological evolution of oceanic core complexes. Kessel et al. [2005] showed that presence of $\mathrm{H}_{2} \mathrm{O}$ leads to a drop in liquidus temperature of basalt and peridotite (Fig. 3). Khedr et al. [2014] showed further that hydrous peridotites in central Japan lithified at 650$750{ }^{\circ} \mathrm{C}$ and circa $1.5 \mathrm{GPa}(\sim 45 \mathrm{~km})$, together with serpentine, antigorite, and other hydrous silicates. Rouméjon et al. [2015] sampled serpentinized peridotites in the NE edge of the SW Indian Ridge where the serpentinization is amagmatic. They concluded that the serpentinization there occurred at $\sim 300^{\circ}$ and the seawater content was $>10 \%$. Guillot et al. [2015], who reported on the significant buoyancy of serpentinites, presumed that the serpentinites could contribute to peridotite exhumation at the seafloor, and thus supported the Francheteau et al. [1976] model of diapiric geodynamics of these hydrous silicates.

The geological, geophysical and geochemical data sets acquired at oceanic core complexes are equivocal whether the exhumation of mantle petrologies is carried out through detachment faults or other type of ascent, and they are nebulous regarding the reason for the occurrence of the complexes at the intersections of fracture zones and slow-spreading ridges. Bearing these doubts in mind, the herein presented concept

\section{REFERENCES}

Agostini A., Corti G., Zeoli A., Mulugeta G., 2009. Evolution, pattern, and partitioning of deformation during oblique continental rifting: Inferences from lithospheric-scale centrifuge models. Geochemistry, Geophysics, of subduction and subsequent diapiric exhumation at the slowridge-fracture zone intersections seems to be a plausible concept for the geodynamics of oceanic core complexes.

\section{CONCLUSIONS}

The presented conceptual model for the geodynamics of oceanic core complexes merges the findings of structural analog experiments of the initiation of subduction with structural and petrological data from these features to suggest the plausibility of the following sequence of events that generated these deep-sea features.

The geographic distribution of many oceanic core complexes at the intersection of slow Mid-Ocean Ridges and fracture zones presents the juxtaposition of the hot, light and fresh oceanic crust in the accretion ridge against older and denser oceanic crust across the fracture zone. That juxtaposition of two lithospheric segments across the shattered vertical zone would enhance the denser slab to be thrust under the lighter one, and the shattered rocks along the fracture zone would serve as a ready and well-lubricated conduit for the initiation of subduction.

The anomalous heat gradient at the active spreading ridge causes the underthrust slab to reach temperatures of remineralization at depth of 4-5 km. The oceanic lithosphere of basalt and gabbro, with ample presence of seawater, is likely to remineralize pyroxenes and olivines into some hydrous silicate like serpentine under the low pressure and high temperature. The exothermic serpentinization is likely to raise the temperature of the environment of the subducting slab further to reach the solidus of wet gabbro, which could lithify as peridotite, which, in turn would account for the co-occurrence of the serpentinites and the peridotites.

The low density of the serpentinite and the abundant shattered and metamorphosed rock at the top of many oceanic core complexes could account for a diapiric ascent of the lighter segments of the subducting mass to return to the seafloor, carrying along blocks of peridotites, and inject these unique lithologies of the oceanic core complex into the ridge-fracture zone intersection.

\section{ACKNOWLEDGEMENTS}

The experiments of the initiation of subduction were carried out courtesy of the Institute of Geology in the University of Uppsala, Sweden, and the experiments on oblique rifting were conducted in the tectonic laboratory in the University of Rennes 1, in Rennes, France. Specifically I am grateful to Christopher Talbot and Hemin Koyi of Uppsala and Jean-Pierre Brun and Olivier Dauteuil of Rennes. The help of two reviewers from Geodynamics and Tectonophysics" is deeply appreciated. I thank Oksana Lunina for her advice and encouragement.

Ahrens T., Schubert G., 1975. Gabbro-eclogite reaction rate and its geophysical significance. Reviews of Geophysics 13 (2), 383-400. https://doi.org/10.1029/RG013i002p00383. 
Andreani M., Mevel C., Boullier A.-M., Escartin J., 2007. Dynamic control on serpentine crystallization in veins: Constraints on hydration processes in oceanic peridotites. Geochemistry, Geophysics, Geosystems 8 (2), Q02012. https:// doi.org/10.1029/2006GC001373.

Benioff $H .$, 1951. Global strain accumulation and release as revealed by great earthquakes. Geological Society of America Bulletin 62 (4), 331-338. https://doi.org/10.1130/ 0016-7606(1951)62[331:GSAARA]2.0.CO;2.

Bonatti E., 1968. Ultramafic rocks from the Mid-Atlantic Ridge. Nature 219 (5152), 363-364. https://doi.org/10. 1038/219363a0.

Boutelier D., Beckett D., 2018. Initiation of subduction along oceanic transform faults: insights from three-dimensional analog modeling experiments. Frontiers in Earth Science 6, 204. https://doi.org/10.3389/feart.2018.00204.

Brune S., Williams S., Mueller D., 2018. Oblique rifting: the rule, not the exception. Solid Earth 9 (5), 1187-1206. https://doi.org/10.5194/se-9-1187-2018.

Cann J.R., Blackman D.K., Smith D.K., McAllister E., Janssen B., Mello S., Avgerinos E., Pascoe A.R., Escartin J., 1997. Corrugated slip surfaces formed at ridge-transform intersections on the Mid-Atlantic Ridge. Nature 385 (6614), 329332. https://doi.org/10.1038/385329a0.

Cannat M., Bideau D., Bougault H., 1992. Serpentinized peridotites and gabbros in the Mid-Atlantic Ridge axial valley at $15^{\circ} 37^{\prime} \mathrm{N}$ and $16^{\circ} 52^{\prime} \mathrm{N}$. Earth and Planetary Letters 109 (1-2), 87-106. https://doi.org/10.1016/0012-821X (92)90076-8.

Cannat. M., Bideau. D., Hebert. R., 1990. Plastic deformation and magmatic impregnation in serpentinized ultramafic rocks from the Garrett transform fault (East Pacific Rise). Earth and Planetary Science Letters 101 (2-4), 216-232. https://doi.org/10.1016/0012-821X(90)90155-Q.

Cannat M., Mevel C., Maia M., Deplus C., Durand C., Genite P., Agrinier P., Ballarouchi A., Dubuisson G., Hurnier E., Reynolds J., 1995. Thin crust, ultramafic exposures, and rugged faulting patterns at the Mid-Atlantic Ridge $\left(22^{\circ}-24^{\circ} \mathrm{N}\right)$. Geology 23 (1), 49-52. https://doi.org/10.1130/0091-76 13(1995)023<0049:TCUEAR>2.3.C0;2.

Casey J.F., Dewey J.F., 1984. Initiation of subduction zones along transform and accreting plate boundaries, triplejunction evolution, and forearc spreading centres - implications for ophiolitic geology and obduction. In: I.G. Gass, S.J. Lippard, A.W. Shelton (Eds), Ophiolites and Oceanic Lithosphere. Geological Society, London, Special Publications, vol. 13, p. 269-290. https://doi.org/10.1144/GSL. SP.1984.013.01.22.

Chemenda A.I., Mattauer M., Malavieille J., Bokun A.N., 1995. A mechanism for syn-collisional rock exhumation and associated normal faulting: Results from physical modelling. Earth and Planetary Science Letters 132 (1-4), 225-232. https://doi.org/10.1016/0012-821X(95)00042-B.

Constantin M., Hekinian R., Ackermand D., Stoffers P., 1995. Mafic and ultramafic intrusions into upper mantle peridotites from fast spreading centers of the Easter Microplate (South East Pacific). In: R.L.M. Vissers, A. Nicolas (Eds), Mantle and lower crust exposed in oceanic ridges and in ophiolites. Springer, Netherlands, p. 71-120.
Dannowski A., Grevenmeyer I., Ranero C.R., Ceuleneer G., Maia M., Morgan J.P., Gente P., 2010. Seismic structure of an oceanic core complex at the Mid-Atlantic Ridge, $22^{\circ} 19^{\prime} \mathrm{N}$. Journal of Geophysical Research: Solid Earth 115 (B7), B07106. https://doi.org/10.1029/2009JB006943.

Dewey J.F., Casey J.F, 2011. The origin of obducted largeslab ophiolite complexes. In: D. Brown, P.D. Ryan (Eds), Arccontinent collision. Springer, Berlin, p. 431-444. https:// doi.org/10.1007/978-3-540-88558-0_15.

Dick H.J.B., 1989. Abyssal peridotites, very slow spreading ridges and ocean ridge magmatism. In: A.D. Saunders, M.J. Norry (Eds), Magmatism in the Ocean Basins. Geological Society, London, Special Publications, vol. 42, p. 71-105. https://doi.org/10.1144/GSL.SP.1989.042.01.06.

Dick H.J.B., Bullen T., 1984. Chromian spinel as a petrogenetic indicator in abyssal and alpine-type peridotites and spatially associated lavas. Contributions to Mineralogy and Petrology 86 (1), 54-76. https://doi.org/10.1007/ BF00373711.

Dick H.J.B., Tivey M.A., Tucholke B.E., 2008. Plutonic foundation of a slow-spreading ridge segment: Oceanic core

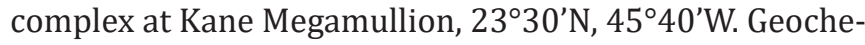
mistry, Geophysics, Geosystems 9 (5), Q05014. https:// doi.org/10.1029/2007GC001645.

Escartin J., Smith D.K., Cann J., Schouten H., Langmuir C.H., Escrig S., 2008. Central role of detachment faults in accretion of slow-spreading oceanic lithosphere. Nature 455 (7214), 790-794. https://doi.org/10.1038/nature 07333.

Ewing J., Ewing M., 1959. Seismic refraction measurements in the Atlantic Ocean basins, in the Mediterranean Sea, on the Mid-Atlantic Ridge, and in the Norwegian Sea. Geological Society of America Bulletin 70 (3), 291-318. https://doi.org/10.1130/0016-7606(1959)70[291:SMI TAO]2.0.CO;2.

Fossen H., 2016. Structural Geology. Second Edition. Cambridge University Press, Cambridge, 503 p.

Francheteau J., Choukroune P., Hekinian R., Le Pichon X., Needham H.D., 1976. Oceanic fracture zones do not provide deep sections in the crust. Canadian Journal of Earth Sciences 13 (9), 1223-1235. https://doi.org/10.1139/ e76-124.

Gerya T.V., 2011. Intra-oceanic subduction zones. In: D. Brown, P.D. Ryan (Eds), Arc-continent collision. Springer, Berlin, p. 23-53. https://doi.org/10.1007/978-3-54088558-0_2.

Ghose I., Cannat M., Seyler M., 1996. Transform fault effect on mantle melting in the MARK area (Mid-Atlantic Ridge south of the Kane transform). Geology 24 (12), 11391142. https://doi.org/10.1130/0091-7613(1996)024<1 139:TFEOMM>2.3.CO;2.

Goren L., Aharonov E., Mulugeta G., Koyi H.A., Mart Y., 2008. Ductile deformation of passive margins: A new mechanism for subduction initiation. Journal of Geophysical Research: Solid Earth 113 (B8), B08411. https://doi.org/ 10.1029/2005JB004179.

Guillot S.P., Schwartz S.P., Reynard B., Agard P., Prigent C.C., 2015. Tectonic significance of serpentinites. Tectonophysics 646, 1-19. https://doi.org/10.1016/j.tecto.2015.01.020. 
Hawkins J.W., 2003. Geology of supra-subduction zones: Implications for the origin of ophiolites. In: Y. Dilek, S. Newcomb (Eds), Ophiolite concept and the evolution of geological thought. Geological Society of America Special Paper, vol. 373, p. 227-268. https://doi.org/10.1130/08137-2373-6.227.

Hékinian R., Bideau D., Hébert R., Niu Y., 1995. Magmatism in the Garrett transform fault (East Pacific Rise near $1327^{\prime} \mathrm{S}$ ). Journal of Geophysical Research: Solid Earth 100 (B6), 10163-10185.https://doi.org/10.1029/ 94JB 02125.

Hess H.H., 1955. Serpentinites, orogeny and epeirogeny. In: A. Poldervaart (Ed.), Crust of the Earth: A Symposium. Geological Society of America Special Paper vol. 62, p. 391-408. https://doi.org/10.1130/SPE62-p391.

Jarrard R.D., 1986. Relations among subduction parameters. Reviews of Geophysics 24 (2), 217-284. https:// doi.org/10.1029/RG024i002p00217.

John B.E., Cheadle M.J., 2010. Deformation and alteration associated with oceanic and continental detachment fault systems: are they similar? In: P.A. Rona, C.W. Devey, J.D. Bramley, J. Murton (Eds), Diversity of hydrothermal systems on slow spreading ocean ridges. Geophysical Monograph Series, vol. 188, p. 175-205. https://doi.org/10.1029/ 2008 GM000772.

Katz R.F., Spiegelman M., Langmuir C.H., 2003. A new parameterization of hydrous mantle melting. Geochemistry, Geophysics, Geosystems 4 (9), 1073. https://doi.org/ 10.1029/2002GC000433.

Kelemen P.B., Kikawa E., Miller D.J., and Shipboard Scientific party, 2007. 1. Leg 209 summary: processes in a 20-km-thick conductive boundary layer beneath the MidAtlantic Ridge, $14^{\circ}-16^{\circ} \mathrm{N}$. Scientific Results, Ocean Drilling Program, College Station, TX, 209, p. 1-33.

Kessel R., Ulmer O., Pettke T., Schmidt M.W., Thompson A.B., 2005. The water-basalt system at 4 to $6 \mathrm{GPa}$ : Phase relations and second critical endpoint in a K-free eclogite at 700 to $1400{ }^{\circ} \mathrm{C}$. Earth and Planetary Science Letters 237 (3-4), 873-892. https://doi.org/10.1016/j.epsl. 2005.06.018.

Khedr M.Z., Arai S., Python M., Tamura A., 2014. Chemical variations of abyssal peridotites in the central Oman ophiolite: Evidence of oceanic mantle heterogeneity. Gondwana Research 25 (3), 1242-1262. https://doi.org/10. 1016/j.gr.2013.05.010.

Knott R., Fouquet Y., Honorez J., Peterson S., Bohn M., 1998. Petrology of hydrothermal mineralization: a vertical section through the TAG mound. In: P.M. Herzig, S.E. Humphris, D.J. Miller, R.A. Zierenberg (Eds), Proceedings of the Ocean Drilling Program, Scientific Results, vol. 158, Ocean Drilling Program, Texas, A \& M University, College Station, TX, p. 5-26.

Le Pichon X., Sibuet J.-C., 1981, Passive margins: A model of formation. Journal of Geophysical Research: Solid Earth 86 (B5), 3708-3720. https://doi.org/10.1029/JB086i B05p03708.

Maffione M., Thieulot C., van Hinsbergen D.J.J., Morris A., Plümper O., Spakman W., 2015. Dynamics of intraoceanic subduction initiation: 1. Oceanic detachment fault inversion and the formation of supra-subduction zone ophiolites.
Geochemistry, Geophysics, Geosystems 16 (6), 1753-1770. https://doi.org/10.1002/2015GC005746.

Mart Y., Aharonov E., Mulugeta G., Ryan W., Tentler T., Goren $L ., 2005$. Analogue modelling of the initiation of subduction. Geophysical Journal International 160 (3), 1081-1091. https: //doi.org/10.1111/j.1365-246X.2005.02544.x.

Mart Y., Dauteuil O., 2000. Analogue experiments of propagation of oblique rifts. Tectonophysics 316 (1-2), 121-132. https://doi.org/10.1016/S0040-1951(99)00231-0.

McCaig A. M., Delacour A., Fallick A.E., Castelain T., FrühGreen $G$., 2010. Detachment fault control on hydrothermal circulation systems: Interpreting the subsurface beneath the TAT hydrothermal field using the Isotopic and geological evolution of oceanic core complexes in the Atlantic. In: P.A. Rona, C.W. Devey, J. Dyment, B.J. Murton (Eds), Diversity of hydrothermal systems on slow spreading ocean ridges. Geophysical Monograph Series, vol. 188, p. 207-239. https:// doi.org/10.1029/2008GM000729.

McKenzie D., 1978. Some remarks on the development of sedimentary basins. Earth and Planetary Science Letters 40 (1), 25-32. https://doi.org/10.1016/0012-821X(78) 90071-7.

Mével C., 2003. Serpentinization of abyssal peridotites at mid-ocean ridges. Comptes Rendus Geoscience 335 (10-11), 825-852. https://doi.org/10.1016/j.crte.2003.08.006.

Mortimer E., Paton D.A., Scholz C.A., Strecker M.R., Blisniuk P., 2007, Orthogonal to oblique rifting: effect of rift basin orientation in the evolution of the North basin, Malawi Rift, East Africa. Basin Research 19 (3), 393-407. https:// doi.org/10.1111/j.1365-2117.2007.00332.x.

Mulugeta G., 1988. Squeeze box in a centrifuge. Tectonophysics 148 (3-4), 323-335. https://doi.org/10.1016/ 0040-1951(88)90139-4.

Nikolaeva K., Gerya T.V., Marques F.O., 2010. Subduction initiation at passive margins: Numerical modeling. Journal of Geophysical Research: Solid Earth 115 (B3), B03406. https://doi.org/10.1029/2009JB006549.

Ohara Y., Yoshida T., Kato Y., Kasuga S., 2001. Giant Megamullion in the Parece Vela backarc basin. Marine Geophysical Researches 22 (1), 47-61. https://doi.org/10.1023/ A:1004818225642.

Parnell-Turner R., Sohn R.A., Peirce C., Reston T.J., MacLeod C.J., Searle R.C., Simão N.M., 2017. Oceanic detachment faults generate compression in extension. Geology 45 (10), 923-926. https://doi.org/10.1130/G39232.1.

Rouméjon S., Cannat M., Agrinier P., Godard M., Andreani $M ., 2015$. Serpentinization and fluid pathways in tectonically exhumed peridotites from the Southwest Indian Ridge (62-65 ${ }^{\circ} \mathrm{E}$ ). Journal of Petrology 56 (4), 703-734. https://doi.org/10.1093/petrology/egv014.

Scholz C.H., 2002. The Mechanics of Earthquakes and Faulting. Second Edition. Cambridge University Press, Cambridge, $485 \mathrm{p}$.

Scholz C.H., Campos J., 1995. On the mechanism of seismic decoupling and the back arc spreading at subduction zones. Journal of Geophysical Research: Solid Earth 100 (B11), 22103-22115. https://doi.org/10.1029/95JB01869.

Sclater J.G., Francheteau J., 1970. The implications of terrestrial heat flow observations on current tectonic and 
geochemical models of the crust and upper mantle of the Earth. Geophysical Journal of the Royal Astronomical Society 20 (5), 509-542. https://doi.org/10.1111/j.1365-246X. 1970.tb06089.x.

Shemenda A.I., 1993. Subduction of the lithosphere and back arc dynamics: Insights from physical modeling. Journal of Geophysical Research: Solid Earth 98 (B9), 1616716185. https://doi.org/10.1029/93JB01094.

Sibuet J.-C., Tucholke B.E., 2013. The geodynamic province of transitional lithosphere adjacent to magma-poor continental margins. In: W.U. Mohriak, A. Danforth, P.J. Post, D.E. Brown, G.C. Tari, M. Nemčok, S.T. Sinha (Eds), Conjugate divergent margins. Geological Society, London, Special Publications, vol. 369, p. 429-452. https://doi.org/ 10.1144/SP369.15.

Smith D.K., Cann J.R., Escartin J., 2006. Widespread active detachment faulting and core complex formation near $13^{\circ} \mathrm{N}$ on the Mid-Atlantic Ridge. Nature 442 (7101), 440443. https://doi.org/10.1038/nature04950.

Stein S., Stein C.A., 1996. Thermo-mechanical evolution of oceanic lithosphere: implications for the subduction process and deep earthquakes. In G.E. Bebout, D.W. Scholl, S.H. Kirby, J.P. Platt (Eds), Subduction: top to bottom. Geophysical
Monograph Series, vol. 96, p. 1-18. https://doi.org/10.1029/ GM096p0001.

Taylor B., Goodliffe A., Martinez F., 2009. Initiation of transform faults at rifted continental margins. Comptes Rendus Geoscience 341 (5), 428-438. https://doi.org/10.1016/j. crte.2008.08.010.

Tucholke B.E., Jian L., Kleinrock M.C., 1998. Megamullions and mullion structure defining oceanic metamorphic core complexes on the Mid-Atlantic Ridge. Journal of Geophysical Research: Solid Earth 103 (B5), 9857-9866. https:// doi.org/10.1029/98JB00167.

Turner F.J., Verhoogen J., 1960. Igneous and Metamorphic Rocks. McGraw - Hill Book Co., New York, 694 p.

Wernicke B., 1985. Uniform-sense normal simple shear of the continental lithosphere. Canadian Journal of Earth Sciences 22 (1), 108-125. https://doi.org/10.1139/e85-009.

Whitney D.L., Teyssier C., Rey P., Buck W.R., 2013. Continental and oceanic core complexes. Geological Society of America Bulletin 125 (3-4), 273-298. https://doi.org/10. 1130/B30754.1.

Wilson J.T., 1965. A new class of faults and their bearing on continental drift. Nature 207 (4995), 343-347. https:// doi.org/10.1038/207343a0.

\section{YOSSI MART}

\section{Professor}

Recanati Institute of Maritime Studies, University of Haifa Haifa 3498838, Israel

e-mail: yossimart@gmail.com

ORCID ID: 0000-0001-5289-0584
ЙОССИ МАРТ

Профессор

Институт морских исследований им. Леона Реканати, Университет Хайфы

3498838, г. Хайфа, Израиль 